\title{
KEMIRIPAN LIPSTIK BERDASARKAN METODE FUZZY C-MEANS (FCM)
}

\author{
Chandra Dharsni, A.A Ngurah Gunawan, Hery Suyanto \\ Jurusan Fisika, Fakultas Matematika dan Ilmu Pengetahuan Alam, Universitas Udayana \\ c.dharsni@unud.ac.id
}

\begin{abstract}
Laser Induced Breakdown Spectroscopy (LIBS) is a spectroscopic method for quantitative and qualitative analysis of elements contained in a material. This technique is based on an analysis of plasma emissions produced by focusing a high-power pulse laser on a sample. However, to determine the similarity of the content of a material based on spectroscopy is difficult, especially for similar materials. Lipstick itself has many color variations and some colors look almost the same. To distinguish each color, lipstick manufacturers give numbers or names on this product. In this case the writer has the goal to see the similarity of characters in the lipstick based on the cluster. For that we need the help of additional software analysis to distinguish or look for similarities of samples. One analysis that can be done is by the fuzzy method. Fuzzy c-means (FCM) is a clustering algorithm where one object can be a member of several clusters based on similar characteristics. In this study the intensity of the data processing of 3 lipstick materials was conducted using clustering method which aims to determine the similarity between materials using Delphi. There are 3 cluster centers that represent each material. From the results of the cluster center found that material 1 and 2 are in one cluster while material 3 is in a different cluster.
\end{abstract}

Keywords: Laser Induced Breakdown Spectroscopy (LIBS), lipstik, cluster, fuzzy c-means (FCM), Delphi.

\begin{abstract}
Abstrak
Laser Induced Breakdown Spectroscopy (LIBS) adalah metode spektroskopi untuk analisis kuantitatif dan kualitatif unsur yang terkandung dalam sebuah bahan. Teknik ini didasarkan pada analisis emisi plasma yang dihasilkan dengan cara memfokuskan laser pulsa berdaya tinggi pada sampel. Namun, untuk menentukan kemiripan kandungan suatu bahan berdasarkan spektroskopi adalah sulit dilakukan terutama untuk bahan yang sejenis. Lipstik sendiri memiliki banyak variasi warna dan beberapa warna tampak hampir sama. Untuk membedakan tiap warna, produsen lipstik memberi nomor atau nama pada produk ini. Dalam hal ini penulis memiliki tujuan untuk melihat kesamaan karakter dalam lipstick berdasarkan klasternya. Untuk itu perlu bantuan analisis software tambahan untuk membedakan atau mencari kemiripan sampel. Salah satu analisis yang dapat dilakukan adalah dengan metode fuzzy. Fuzzy c-means (FCM) adalah algoritma clustering dimana satu objek dapat menjadi anggota beberapa cluster berdasarkan kesamaan karakteristiknya. Pada penelitian ini dilakukan pengolahan data intensitas dari 3 bahan lipstik dengan metode clustering yang bertujuan untuk mengetahui kemiripan antar bahan menggunakan Delphi. Terdapat 3 pusat cluster yang mewakili masing-masing bahan. Dari hasil pusat
\end{abstract}


klaster didapat bahwa bahan 1 dan 2 berada pada satu klaster sedangkan bahan 3 berada di klaster yang berbeda.

Kata kunci: Laser Induced Breakdown Spectroscopy (LIBS), lipstik, klaster, fuzzy c-means (FCM), Delphi.

\section{PENDAHULUAN}

Clustering adalah suatu metode pengelompokan berdasarkan ukuran kedekatan atau kemiripan. Clustering berbeda dengan group, group merupakan kelompok yang memiliki kondisi yang sama. Sedangkan cluster kelompoknya tidak harus sama, pengelompokan didasarkan pada kedekatan dari suatu karakteristik sampel yang ada [8]. Tujuan utama analisis cluster adalah mengelompokkan objekobjek berdasarkan kesamaan karakteristik di antara objek-objek tersebut. Objek tersebut akan diklasifikasikan ke dalam satu atau lebih cluster (kelompok) sehingga objek-objek yang berada dalam satu cluster akan mempunyai kemiripan satu dengan yang lain. Analisis cluster mengklasifikasi objek sehingga setiap objek yang memiliki sifat yang mirip (paling dekat kesamaannya) akan mengelompok kedalam satu cluster yang sama. Cluster yang baik adalah cluster yang mempunyai kesamaan yang tinggi antar anggota dalam satu cluster dan perbedaan yang tinggi antar cluster yang satu dengan cluster yang lainnya. Terdapat banyak sekali algoritma yang digunakan dalam clustering, salah satunya adalah fuzzy c-means (FCM). Konsep dasar fuzzy c-means (FCM), pertama kali adalah menentukan pusat cluster, yang akan menandai lokasi rata-rata untuk tiap cluster [6].

Fuzzy c-means (FCM) adalah algoritma clustering dimana satu objek dapat menjadi anggota beberapa cluster berdasarkan kesamaan karakteristiknya. Setiap titik data memiliki derajat keanggotaan untuk tiap-tiap cluster. Nilai derajat keanggotaan dalam algoritma fuzzy c-means (FCM) adalah antara 0 sampai 1 [2]. Metode fuzzy c-means (FCM) dapat digunakan untuk menentukan karakteristik sampel berdasarkan pada hasil perhitungan pusat cluster sampel dengan melihat kedekatan antar sampel. Kedekatan pusat cluster ini berdasarkan pada kesamaan karakteristik antar sampel. Metode perhitungan fuzzy c-means (FCM) dapat dibuat menggunakan Delphi 7. Delphi 7 adalah suatu bahasa pemograman yang digunakan untuk merancang suatu aplikasi

Lipstik merupakan pewarna bibir yang dikemas dalam bentuk batang padat (stick) yang dibentuk dari minyak, lilin dan lemak [4]. Lipstik sendiri memiliki banyak variasi warna dan beberapa warna tampak hampir sama. Untuk membedakan tiap warna, produsen lipstik memberi nomor atau nama pada produk ini. Dalam hal ini penulis memiliki tujuan untuk melihat kesamaan karakter dalam lipstik revlon super lustrous nomor 125 dan 130 dengan lipstik revlon tanpa nomor yang dibeli di pasar, menggunakan metode clustering. Maka dari itu akan dilakukan penelitian untuk melihat kemiripan lipstik berdasarkan klusternya dengan metode fuzzy c-means menggunakan delphi 7. 


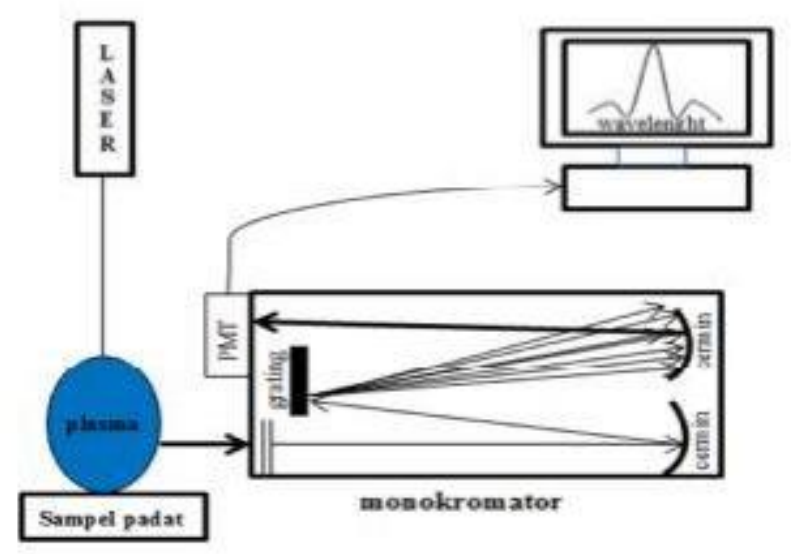

Gambar 1. Skema sederhanan komponen utama Laser Induced Breakdown Spectroscopy (LIBS) [10]

Gambar 1 menunjukkan skema sederhana komponen LIBS. Laser Nd:YAG diarahkan ke permukaan sampel. Sebelum ditembakan, laser harus difokuskan terlebih dahulu di permukaan sampel. Laser yang mengenai permukaan sampel akan membentuk plasma di atas permukaan sampel. Plasma berisikan elektronelektron, ion-ion, atom netral dan atom-atom tereksitasi. Elektron-elektron di dalam atom tereksitasi pindah ke kulit orbit luar dan dengan waktu yang sangat singkat akan kembali lagi ke keadaan dasar (ground state) sambil mengemisikan foton dengan panjang gelombang tertentu sesuai jenis unsurnya.

Emisi foton ini selanjutnya masuk ke slit monokromator, kemudian diuraikan oleh grating atau kisi menuju cermin dan dipantulkan ke sensor dan diperkuat oleh Photo Multiplayer Tube (PMT). Sinyal yang keluar dari PMT ditampilkan di layar komputer berupa spektrum grafik intensitas fungsi panjang gelombang. Dari spektrum tersebut bisa dilakukan analisis kualitatif dan kuantitatif. Analisis kualitatif adalah identifikasi unsur-unsur atau molekul yang terkandung dalam bahan, sedangkan analisis kuantitatif adalah kadar unsur-unsur atau molekul yang terkandung dalam bahan [10].

Algoritma Fuzzy C-Means disusun dengan langkah sebagai berikut [7]:

1) Input data yang akan di cluster berupa matrik berukuran $\mathrm{n} \times \mathrm{m}(\mathrm{n}=$ jumlah data, $m=$ atribut setiap data). Xij = data ke-i $(i=1,2, \ldots, n)$, atribut ke-j $(j=1,2, \ldots, m)$.

2) Tentukan:
a. Pangkat $=\mathrm{w}$
b. Maksimum iterasi $=$ MaxIter
c. Error terkecil yang diharapkan $=\xi$.
d. Fungsi obyektif awal $=\mathrm{P}_{0}=0$ 
e. Iterasi awal $=\mathrm{t}=1$

3) Membangkitkan bilangan random $\mu \mathrm{ik}, \mathrm{i}=1,2, \ldots, \mathrm{n} ; \mathrm{k}=1,2, \ldots, \mathrm{c}$; sebagai elemen-elemen matrik partisi awal $\mathrm{U}$

4) Hitung pusat cluster ke-k: $V_{k j}$, dengan $k=1,2, \ldots, c ;$ dan $j=1,2, \ldots, m$.

$$
V_{k j}=\frac{\sum_{i=1}^{\mathrm{n}}\left(\left(\mu_{i k}\right)^{w} * X_{i j}\right)}{\sum_{i=1}^{\mathrm{n}}\left(\mu_{i k}\right)^{w}}
$$

5) Hitung fungsi obyektif pada iterasi ke-t, $\mathrm{P}_{\mathrm{t}}$ :

$$
P_{t}=\sum_{i=1}^{n} \sum_{k=1}^{e}\left(\left[\sum_{j=1}^{m}\left(X_{i j}-V_{k j}\right)^{2}\right]\left(\mu_{i k}\right)^{w}\right)
$$

6) Hitung perubahan matriks partisi:

$$
\mu_{i k}=\frac{\left[\sum_{j=1}^{m}\left(x_{i j}-V_{k j}\right)^{2}\right]^{\frac{-1}{w-1}}}{\sum_{k=1}^{c}\left[\sum_{j=1}^{m}\left(x_{i j}-V_{k j}\right)^{2}\right]^{-1}}
$$

dengan: $\mathrm{i}=1,2, \ldots, \mathrm{n} ;$ dan $\mathrm{k}=1,2, \ldots, \mathrm{c}$.

7) Cek kondisi berhenti:

a) Jika: $\left(\left|\mathrm{P}_{\mathrm{t}}-\mathrm{P}_{\mathrm{t}-1}\right|<\xi\right)$ atau $(\mathrm{t}>$ MaxIter) maka berhenti;

b) Jika tidak: $\mathrm{t}=\mathrm{t}+1$, ulangi langkah ke-4.

Dalam analisis klaster, pengelompokan objek didasarkan atas kesamaan atau ketidaksamaan [5]. Analisis klaster adalah suatu teknik statistik yang bertujuan untuk mengelompokkan objek ke dalam suatu kelompok sedemikian sehingga objek yang berada dalam satu kelompok akan memiliki kesamaan yang tinggi dibandingkan dengan objek yang berada di kelompok lain. Centroid linkage adalah rata-rata semua objek dalam klaster. Jarak antara dua klaster adalah jarak antar centroid klaster tersebut. Dengan metode ini, setiap terjadi klaster baru segera terjadi perhitungan ulang centroid sampai terbentuk klaster yang tetap [9].

Dalam pemrograman delphi, istilah obyek-obyek disebut dengan control atau komponen. Komponen adalah blok-blok bagian yang akan membentuk suatu aplikasi delphi. Komponen-komponen tersebut dapat dilihat pada window component palette. Untuk menempatkan sebuah komponen ke sebuah window, cukup dengan mengklik komponen dari component palette kemudian mengklik lokasi tempat penempatan komponen tersebut di dalam form. Setiap komponen mempunyai atribut tertentu untuk mengatur aplikasi ketika waktu desain atau waktu dijalankan (run time)[1].

\section{METODOLOGI PENELITIAN}

Diagram alur pelaksanaan penelitian dapat dilihat pada Gambar 2 


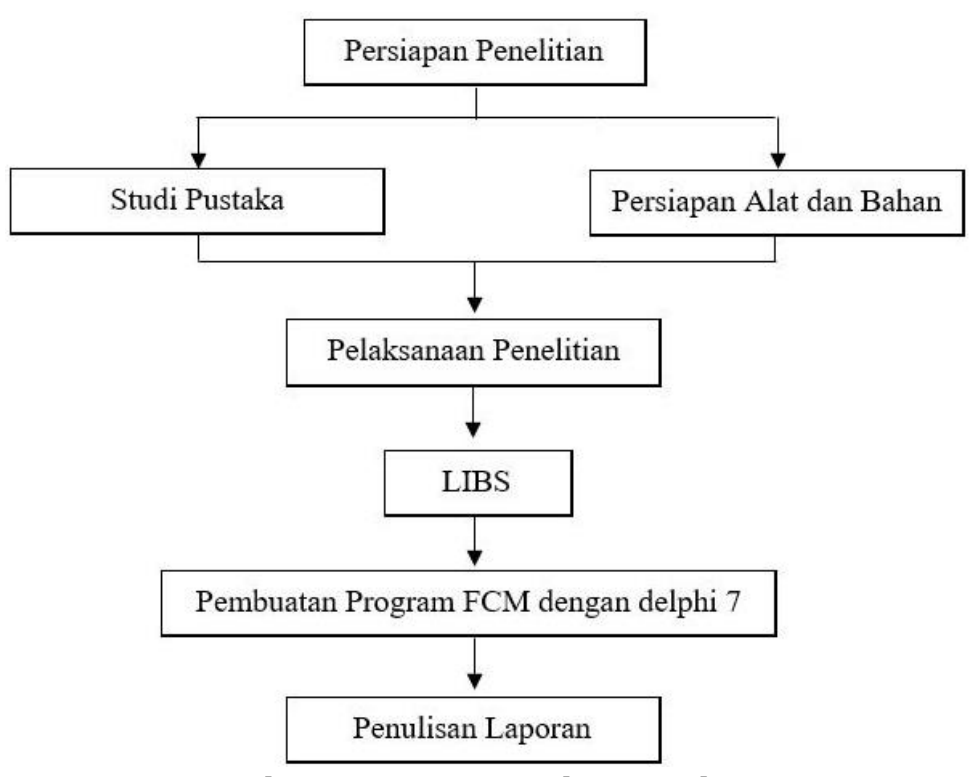

Gambar 2. Diagram Alir Penelitian

Menentukan kemiripan dari suatu bahan memerlukan beberapa tahapan. Adapun langkah-langkah yang dilalui seperti menentukan panjang gelombang dan intensitas dari bahan yaitu menggunakan Laser Induced Breakdown Spectroscopy (LIBS) yang kemudian data diolah dalam program.

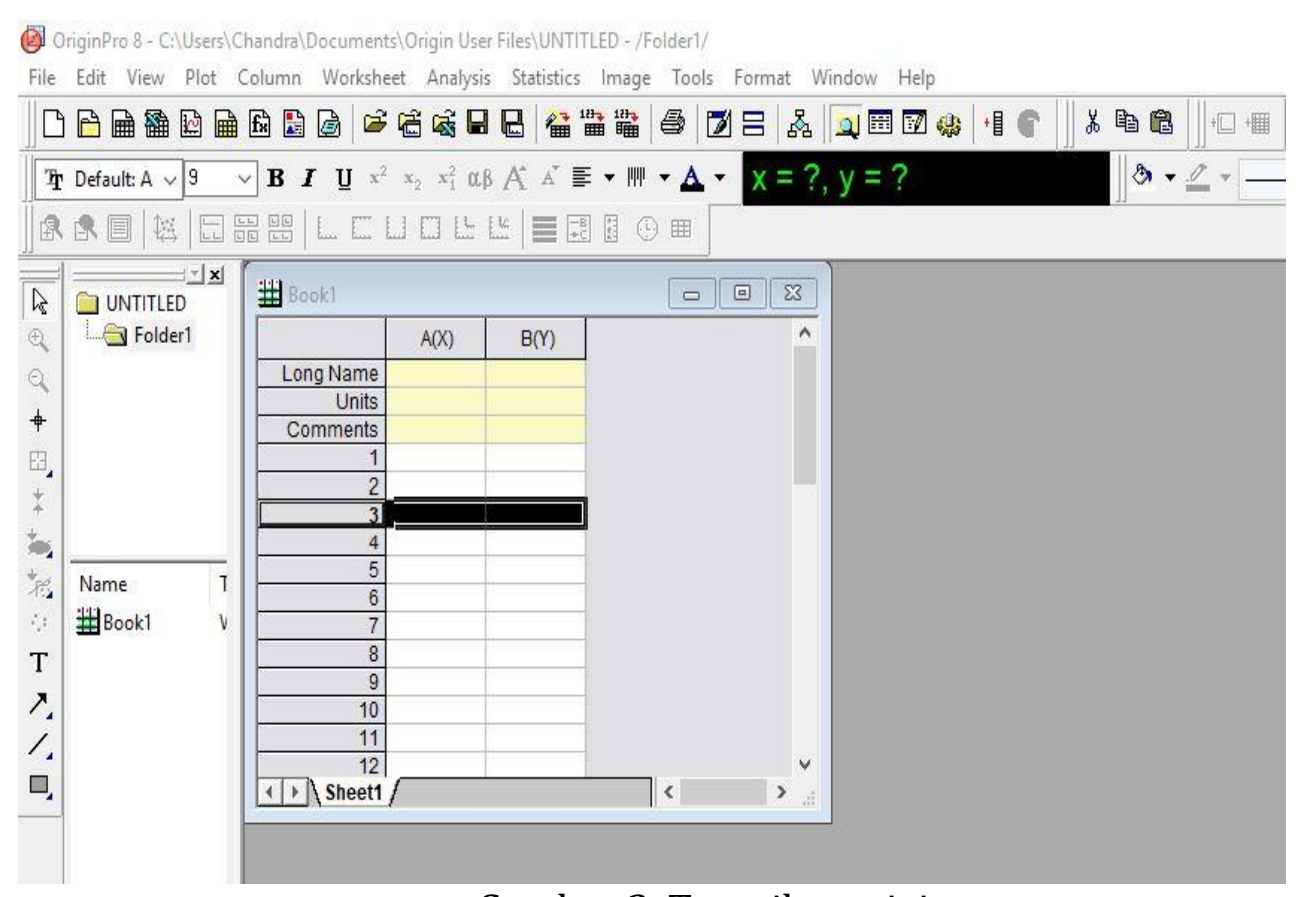

Gambar 3. Tampilan origin

Data panjang gelombang dan intensitas di salin ke dalam tabel $\mathrm{A}(\mathrm{X})$ dan $\mathrm{B}(\mathrm{Y})$, kemudian dipilih menu plot untuk menampilkan intensitas spektrum. Spektrum yang ditampilkan dapat diperbesar dan diperkecil agar memudahkan dalam memilih titik - titik puncak. Titik inilah yang kemudian di perbesar dan 
dapat diambil data intensitas puncak kemudian dikurangi background menggunakan tool screen reader. Data intensitas dan panjang gelombang disimpan di ms.access, kemudian dilakukan koneksi ms.access terhadap delphi 7. Setelah itu, dirancang tampilan aplikasi dan dibuat kode program mengacu pada perhitungan fuzzy c-means (FCM), adapun bagan alir metode fuzzy c-means (FCM) seperti pada Gambar 4

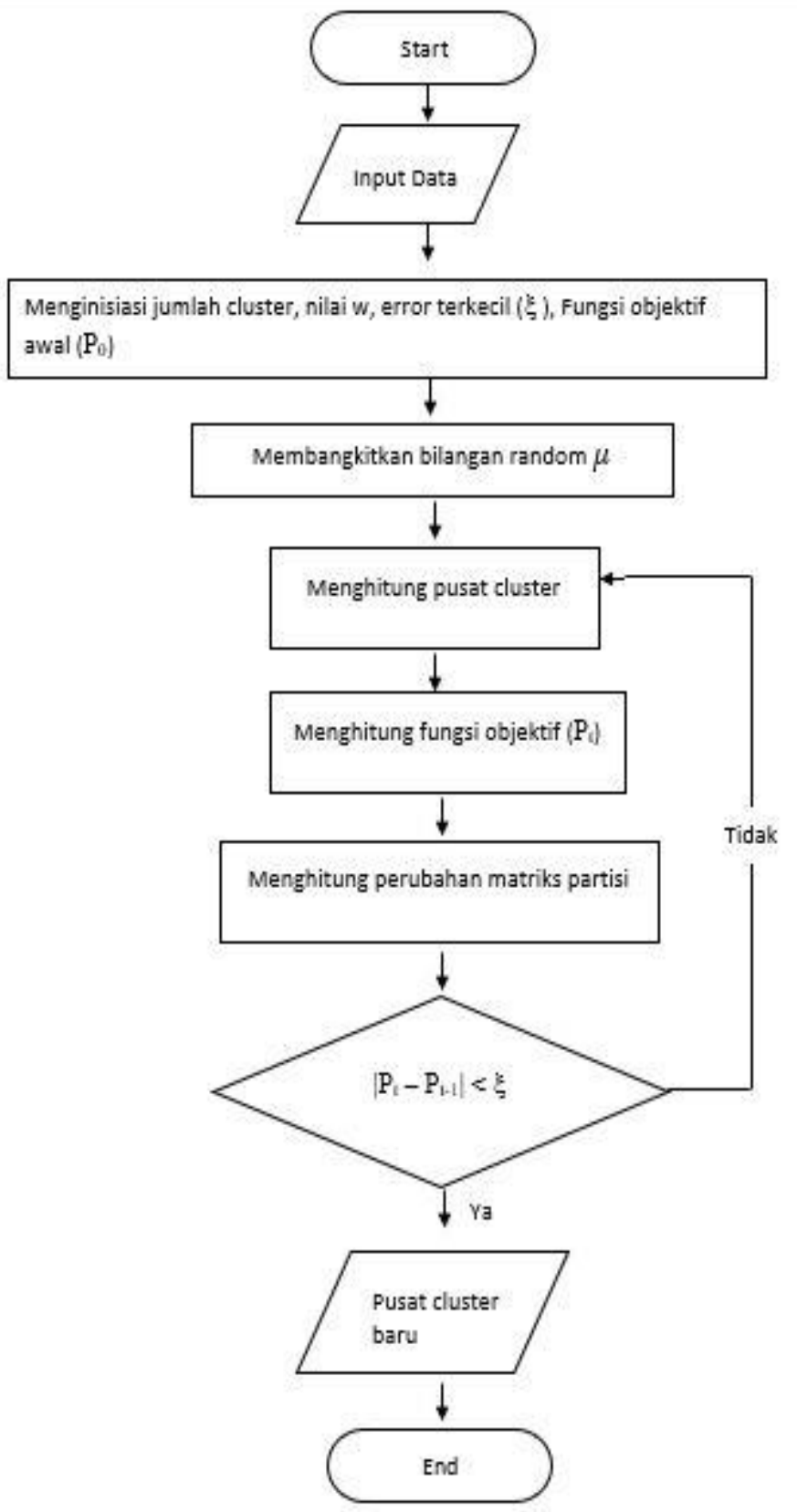

Gambar 4. Bagan alir perhitungan fuzzy c-means [7] 


\section{HASIL DAN PEMBAHASAN}

Berdasarkan data spektra pada tabel 1, maka bahan-bahan tersebut mempunyai unsur-unsur utama penyusun yang mirip, hanya terjadi perbedaan nilai intensitas atau konsentrasinya. Panjang gelombang menunjukkan jenis unsur dalam sampel yang mana digunakan sebagai analisis kualitatif, sedangkan intensitas menyatakan jumlah unsur tersebut dalam sampel yang mana bermanfaat sebagai analisis kuantitatif [3].

Tabel 1. Panjang gelombang dan nilai intensitas bahan dalam lipstik

\begin{tabular}{|c|c|c|c|c|}
\hline No & $\begin{array}{l}\text { Panjang Gelombang } \\
(\mathbf{n m})\end{array}$ & $\begin{array}{l}\text { Intensitas } \\
\text { Bahan } 1\end{array}$ & $\begin{array}{l}\text { Intensitas } \\
\text { Bahan } 2\end{array}$ & $\begin{array}{l}\text { Intensitas } \\
\text { Bahan } 3\end{array}$ \\
\hline 1 & 453,428 & 33,6 & 26,72 & 114.965 \\
\hline 2 & 498,019 & 30,53 & 36,244 & 79.806 \\
\hline 3 & 498,964 & 24,256 & 24,61 & 66.12 \\
\hline 4 & 499,832 & 25,059 & 16,022 & 66.372 \\
\hline 5 & 500,607 & 20,096 & 16,166 & 38.806 \\
\hline 6 & 501,293 & 23,6 & 16,469 & 55.657 \\
\hline 7 & 503,484 & 16,829 & 13,264 & 41.643 \\
\hline 8 & 588,893 & 41,392 & 73,138 & 0 \\
\hline 9 & 589,501 & 24,641 & 52,521 & 95.588 \\
\hline 10 & 656,204 & 46,646 & 50,163 & 54.803 \\
\hline 11 & 742,349 & 14,941 & 16,641 & 13.506 \\
\hline 12 & 744,229 & 35,942 & 36,698 & 34.325 \\
\hline 13 & 744,242 & 36,507 & 42,271 & 0 \\
\hline 14 & 746,86 & 51,51 & 54,549 & 45.608 \\
\hline 15 & 766,489 & 23,304 & 61,008 & 33.78 \\
\hline 16 & 769,873 & 17,78 & 42,72 & 30.152 \\
\hline 17 & 777,194 & 64,84 & 57,941 & 69.47 \\
\hline 18 & 777,417 & 21,992 & 16,36 & 17.792 \\
\hline 19 & 818,702 & 13,143 & 15,524 & 9.686 \\
\hline 20 & 821,582 & 46,259 & 50,148 & 32.103 \\
\hline
\end{tabular}

Secara spektroskopi sulit membedakan atau mencari ciri karakteristik antara satu bahan dengan bahan yang lainnya. Dalam penelitian ini bertujuan untuk menguji 
kemiripan karakteristik bahan, untuk itu perlu dilakukan analisis lebih lanjut yaitu menggunakan perhitungan fuzzy c-means (FCM) dengan delphi 7.

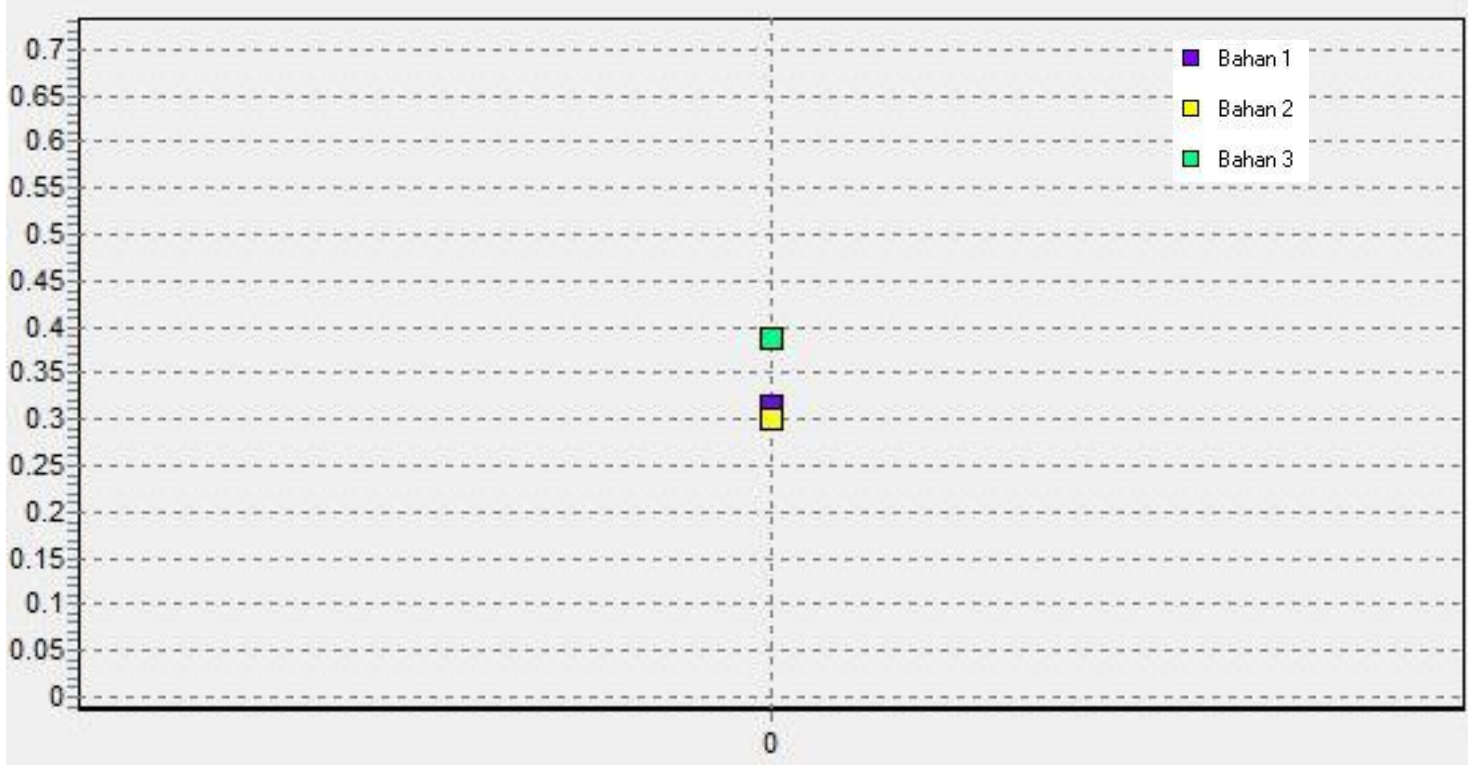

Gambar 5. Tampilan pusat klaster bahan

Pada gambar 5 sumbu Y menunjukkan koefisien titik cluster. Dalam teknik ini, tiap titik data dikelompokkan dalam suatu cluster dengan melakukan perhitungan sampai mendapatkan pusat klasternya (centroid). Adapun korelasi dari data intensitas ke-3 bahan tersebut diatur sedemikian rupa hingga mendapatkan suatu koefisien atau derajat keanggotaan. Setiap koefisien tersebut dibandingkan satu dengan lainnya maka akan didapatkan cluster yang menentukan kedekatan atau kemiripan dari bahan tersebut.

\section{SIMPULAN}

Dari hasil pada Gambar 5, terdapat 3 koefisien pusat cluster yang mewakili masing-masing bahan. Lipstik revlon super lustrous nomor 125 sebagai bahan 1 , lipstik revlon super lustrous nomor 130 sebagai bahan 2, lipstik revlon tanpa nomor sebagai bahan 3. Adanya korelasi antara bahan 1, bahan 2 dan bahan 3 dilihat dari koefisien pusat cluster yang berdekatan. Semakin dekat jarak antar koefisien maka semakin tinggi kemiripan bahan yang digunakan. Pada gambar 5, pusat cluster bahan 1 dan bahan 2 memiliki kemiripan yang tinggi dengan letak yang berdekatan, sementara pusat cluster bahan 3 berjauhan dengan bahan lain sehingga memiliki perbedaan yang tinggi terhadap bahan lain. Dari perbedaan letak ini dapat ditentukan bahwa bahan bahan 1 dan 2 berada pada satu cluster sedangkan bahan 3 berada pada cluster yang berbeda. 


\section{DAFTAR PUSTAKA}

[1] Andoyo, A., Suyono, “Dasar Pemograman Delphi”, Edisi Pertama, Penerbit ANDI, Yogyakarta, 1-13, 2016

[2] Astria, D., Suprayoga, "Penerapan Algoritma Fuzzy C - Means Untuk Clustering Pelanggan Pada CV. Mataram Jaya Bawen", Eksplora Informatika, Vol. 6 No. 2, 170, 2017

[3] Baskoro, W.T., Suyanto, H., “Analisis Signal Latar Plasma Laser dan Effeknya Dengan Laser-Induced Breakdown Spectroscopy (LIBS)", Simposium Fisika Nasional (SFN XXVII), Denpasar,2014

[4] Departemen Kesehatan Republik Indonesia, "Formularium Kosmetika Indonesia", Badan Pengawas Obat dan Makanan, Jakarta, 1985

[5] Hadinata, E., "Pengembangan Algoritma Penentuan Titik Awal Dalam Metode Clustering Algoritma Fuzzy C-Means", Tesis Program Magister S2 Teknik Informatika, Fakultas Ilmu Komputer Dan Teknologi Informasi, Universitas Sumatera Utara, Medan, 2016

[6] Muchsin, A.K., Sudarma.M.,"Penerapan Fuzzy C - Means Untuk Penentuan Besar Uang Kuliah Tunggal Mahasiswa Baru”, Lontar Komputer, Vol. 6 No. $3,177,2015$

[7] Nurjanah, F.A., Indriani, F., “Implementasi Metode Fuzzy C-MEANS Pada Sistem Clustering Data Varietas Padi”, Kumpulan Jurnal Ilmu Komputer (KLIK), Vol. 01 No. 01, 26-27, 2014

[8] Satriyanto, E., “Sebuah catatan ringkas aplikasi statistic (Clustering)", Kangedi.lecturer.pens.ac.id, 2015

[9] Silvi, R., "Analisis Cluster dengan Data Outlier Menggunakan Centroid Linkage dan K-Means Clustering untuk Pengelompokan Indikator HIV/AIDS di Indonesia", Jurnal Matematika "Mantik", Vol.04, No.01, 25,2018

[10] Tussniari, P.E.S., “Ekstrak Antosianin Daging Buah Salak (Salaca Zallacca) untuk Dye Sensitized Solar Cell (DSSC)", Skripsi Program Studi Fisika, Fakultas Matematika dan Ilmu Pengetahuan Alam, Universitas Udayana, Bali, 2018 